\title{
Yield per recruit of the pacu Piaractus mesopotamicus (Holmberg, 1887) in the pantanal of Mato Grosso do Sul, Brazil
}

\author{
Peixer, J. ${ }^{\mathrm{a} *}$, Catella, AC. ${ }^{\mathrm{b}}$ and Petrere Júnior, M. ${ }^{\mathrm{a} *}$ \\ aDepartamento de Ecologia, UNESP, Av. 24A n¹515, CP 199, CEP 13506-900, Rio Claro, SP, Brazil \\ 'EMBRAPA Pantanal, Rua 21 de Setembro, 1880, CP 109, CEP 79320-900, Corumbá, MS, Brazil \\ *e-mail: mpetrere@rc.unesp.br, janicepx@hotmail.com
}

Received October 10, 2005 - Accepted November 16, 2005 - Distributed August 31, 2007

(With 3 figures)

\begin{abstract}
Among the several fish species comercially exploited at the Pantanal of Mato Grosso do Sul, the "pacu" (Piaractus mesopotamicus) stands as one of the most important. Information regarding its exploitation level is necessary for the proper management of its stocks. Between 1996 and 1997 data on total length of the pacu were collected on a monthly basis from specimens caught by professional and sport fishers in the municipality of Corumbá. These data were used to estimate growth parameters and to assess the exploitation level for this species, applying the Beverton and Holt yield per recruit model. Length frequency analysis, carried out with the software FISAT (ELEFAN), was used to estimate growth parameters: $1996: \mathrm{L}_{\infty}=87.20 \mathrm{~cm} ; \mathrm{K}=0.34$ year $^{-1} ; \phi^{\prime}=3.41 ; \mathrm{C}=0.74 ; \mathrm{WP}=0.81$; Longevity $=8.40$ years; and 1997: $\mathrm{L}_{\infty}=86.50 \mathrm{~cm} ; \mathrm{K}=0.34$ year $^{-1} ; \phi^{\prime}=3.40 ; \mathrm{C}=0.60 ; \mathrm{WP}=0.80$; Longevity $=8.40$ years. The value for $\mathrm{t}_{0}$ is -0.363 years for mean values of $\mathrm{L}_{\infty}$ and $\mathrm{k}$. The weight-length relationship, calculated from data derived from experimental fisheries carried out in 1999 and 2000, is described by the equation: $\mathrm{W}=0.048 \mathrm{LF}^{2.835}$. Estimated mortalities and survival rates were: $1996: \mathrm{Z}=1.51$ year $^{-1} ; \mathrm{M}=0.62 \mathrm{year}^{-1} ; \mathrm{F}=0.89$ year $^{-1} ; \mathrm{S}=21.9 \%$; and 1997 : $\mathrm{Z}=1.65$ year $^{-1} ; \mathrm{M}=0.63$ year $^{-1} ; \mathrm{F}=1.02$ year $^{-1} ; \mathrm{S}=19.1 \%$. The yield per recruit analysis showed the following values: $\mathrm{F}_{\text {Present }}=0.96$ year $^{-1} ; \mathrm{F}_{\max }=0.67$ year $^{-1} ; \mathrm{F}_{0.1}=0.51$ year $^{-1}\left(\right.$ for $\left.\mathrm{L}_{\mathrm{c}}=26.7 \mathrm{~cm}\right)$. These results suggest that the pacu is overexploited in the area, so that restrictive measures are in need to manage the pacu fisheries.
\end{abstract}

Keywords: pacu, Piaractus mesopotamicus, yield per recruit, Pantanal, Brazil.

\section{Rendimento por recruta do pacu Piaractus mesopotamicus (Holmberg, 1887) no Pantanal de Mato Grosso do Sul, Brasil}

\begin{abstract}
Resumo
O pacu (Piaractus mesopotamicus) é uma das espécies mais capturadas no Pantanal de Mato Grosso do Sul, e para manejá-lo adequadamente são necessárias informações a respeito do seu nível de explotação. Nos anos de 1996 e 1997 foram coletadas amostras mensais de comprimentos de pacu capturados por pescadores profissionais e esportivos desembarcados em Corumbá, Pantanal de Mato Grosso do Sul (MS), com o objetivo de estimar os parâmetros de crescimento e o seu nível de explotação. Para a determinação do nível de explotação foi utilizado o modelo de rendimento por recruta de Beverton e Holt. Através da análise de frequiência de comprimento, pelo pacote FISAT (ELEFAN), foram estimados os parâmetros de crescimento, com os seguintes valores: $1996: \mathrm{L}_{\infty}=87,20 \mathrm{~cm} ; \mathrm{K}=0,34$ ano $^{-1} ; \phi^{\prime}=3,41$; $\mathrm{C}=0,74 ; \mathrm{WP}=0,81 ;$ Longevidade $=8,40$ anos; e 1997: $\mathrm{L}_{\infty}=86,50 \mathrm{~cm} ; \mathrm{K}=0,34$ ano $^{-1} ; \phi^{\prime}=3,40 ; \mathrm{C}=0,60 ; \mathrm{WP}=0,80$; Longevidade $=8,40$ anos. $\mathrm{O}$ valor de $\mathrm{t}_{0} \mathrm{e}-0,363$ para os valores médios de $\mathrm{L}_{\infty} \mathrm{e} \mathrm{k}$. A relação peso-comprimento foi determinada através de dados de pescarias experimentais em 1999 e 2000, e foi a seguinte: $\mathrm{W}=0,048 \mathrm{LF}^{2.835}$. As taxas de mortalidade estimadas e a taxa de sobrevivência foram: 1996: $\mathrm{Z}=1,51 \mathrm{ano}^{-1} ; \mathrm{M}=0,62$ ano $^{-1} ; \mathrm{F}=0,89$ ano $^{-1} ; \mathrm{S}=21,9 \%$; e 1997: $\mathrm{Z}=1,65 \mathrm{ano}^{-1} ; \mathrm{M}=0,63 \mathrm{ano}^{-1} ; \mathrm{F}=1,02 \mathrm{ano}^{-1} ; \mathrm{S}=19,1 \%$. A análise de rendimento por recruta apresentou os seguintes resultados: $\mathrm{F}_{\text {atual }}=0,96$ ano ${ }^{-1} ; \mathrm{F}_{\text {máx }}=0,67$ ano $^{-1} ; \mathrm{F}_{0,1}=0,51$ ano ${ }^{-1}$ (quando $\mathrm{L}_{\mathrm{c}}=26,7 \mathrm{~cm}$ ). Este resultado indica que o pacu está sobreexplotado, e assim há necessidade de se estabelecer medidas restritivas para sua pescaria.
\end{abstract}

Palavras-chave: pacu, Piaractus mesopotamicus, rendimento por recruta, Pantanal, Brasil.

\section{Introduction}

For an adequate management of a species, detailed information on its growth parameters, as a life-history component, is central in understanding its population

dynamics. Fish growth is highly flexible, as it depends on food availability and temperature (Weatherley, 1972); for species living in highly seasonal floodplain habitats, 
such as the Pantanal, growth also depends on the annual flooding cycles (Barco et al., 1993). Growth parameters can be estimated from morphological analysis of the growth of calcified structures such as otholits and scales, as well as from mark-recapture studies and from length frequency analysis.

The simplest model for the analysis of stock management is based on the surplus production (Hilborn and Walters, 1992). However, this model requires a long series of catch and effort data. Whenever age determination is difficult, or a long series of catch and effort data is unavailable, models based on yield per recruit offer a valuable alternative (Holden, 1995). Holden (1995) suggests that yield per recruit curves offer a simple and clear way for managers involved in fisheries to take decisions regarding, for example, the advantages of reducing mortality rates and/or increasing the minimum age of recruitment for fisheries.

Silva (1986) estimated the mean length of first maturity of the pacu Piaractus mesopotamicus as $43 \mathrm{~cm}$. Ferraz de Lima (1984a) estimated in $42 \mathrm{~cm}$ the mean length for females to be ready for reproduction $\left(\mathrm{L}_{50}\right)$. Based on the surplus production analysis carried out by Catella (2001), the mean minimum length for catch of pacu increased from 40 to $45 \mathrm{~cm}$ in 2000 .

The main objective of this study is to determine the growth parameters for the pacu caught by hook, the only permitted fishing gear in the region, and use them for the yield per recruit analysis.

\section{Material and Methods}

\subsection{Data collection}

Between 1996 and 1997, data on the total length of the pacu were collected on a monthly basis from specimens caught by professional and sport fishers in the municipality of Corumbá, State of Mato Grosso do Sul, Brazil.

The furcal length (FL, cm), the distance between the tip of the nose and the fork of the caudal fin, was used as a proxy for the length measurement. This measurement is easy to obtain using an ichtyometer and thus, relatively free from errors, and avoids the problems associated with mutilated caudal fins.

A research team from EMBRAPA-Pantanal collected data from the professional fisheries. These data were collected from fishes landed at the Cooperativa de Pesca de Corumbá - COOPECOR, from the fish markets of Praia Vermelha and from the Colônia de Pescadores (Fisher's Colony) Z01, at Porto Geral. The fishers of COOPECOR mostly operate along the length of the Paraguay River, above Corumbá, at the lower passage of the Cuiabá River (locally known as São Lourenço River), and at the vicinities of the Pantanal Mato-Grossense National Park. The fish markets at Praia Vermelha acquire the fish caught in the Paraguay River, close to Corumbá, and Z01 operates along the Paraguay River. We did not weigh the fish due to lack of facilities and proper scales at each sampling site.

Data from hook ad line sport fisheries came from fish caught by tourists that use local facilities for fishing in the Pantanal. An employee was trained to collect furcal length data. The sport fishers operated downriver and upriver from Corumbá. These samples were taken just from March to October of 1996 and 1997, due to the fishing ban in the Pantanal which lasts from November to February.

Data from experimental fishing carried out between November 1999 and January 2000, weight (here we could use a scale) and length measurements, were used to establish the relationships between body weight (WC), total length (LT), furcal length (LF) and standard length (LS) for the pacu.

\subsection{Estimate of the von Bertalanffy growth in length model parameters}

Growth parameters were estimated using the program FISAT (FAO-ICLARM Stock Assessment Tools). ELEFAN (Eletronic Length Frequency Analysis; Pauly and David, 1981) is a module within this program that specifically uses length frequency data.

Vaz (2001) compared several methods to estimate growth parameters of pacu and concluded that ELEFAN was the most adequate. She also used scales to identify age rings and carried out a length frequency analysis, concluding that the latter is the most appropriate.

The growth equation used by ELEFAN is the seasonal Von Bertalanffy growth function (VBGF) (Gayanilo and Pauly, 1997).

The current methodology is not fully explained here due to lack of space, although it is explained at length in Sparre and Venema (1997)

\subsection{Index of growth performance ( $\left.\phi^{\prime}\right)$}

This index was calculated according to the formula proposed by Pauly (1979):

$\phi^{\prime}=\log _{10} \mathrm{~K}+2 .\left(\log _{10} \mathrm{~L}_{\infty}\right)$

\subsection{Longevity (Tm)}

Taylor (1960) model was used to estimate longevity:

$$
\mathrm{A}_{0.95}=\mathrm{t}_{0}+\left(\frac{2.996}{\mathrm{~K}}\right)
$$

To estimate $t_{0}$ the empirical formula of Pauly and Martosubroto (1980) was used:

$\log \left(-\mathrm{t}_{0}\right)=-0.3922-0.2752 . \log \mathrm{L}_{\infty}-1.038 . \log \mathrm{K}$

\subsection{Total mortality $(Z)$}

Total mortality rate $(Z)$ was estimated from the equation developed by Beverton and Holt (1956) apud (Gayanilo and Pauly, 1997): 


$$
Z=k\left(\frac{L \infty-\bar{L}}{L \infty-L^{\prime}}\right)
$$

where $\mathrm{Z}=$ Coefficient of total mortality $\left(\right.$ year $\left.^{-1}\right)$; $\mathrm{L}^{\prime}=$ Minimum adopted catch length $(\mathrm{cm})$ (this measure was used because no data on gear selectivity was available; the original equation assumes that this parameter is equal to the smallest length in the sample); and $\overline{\mathrm{L}}=$ Mean length of all fishes with lengths above L' (cm)

Total mortality was also estimated accordingly to Ault and Ehrhardt (1991) apud (Gayanilo and Pauly, 1997):

$$
\begin{aligned}
& {\left[\frac{\mathrm{L} \infty-\mathrm{L}_{\max }}{\mathrm{L} \infty-\mathrm{L}^{\prime}}\right]^{\mathrm{Z} / \mathrm{K}}=} \\
& {\left[\frac{\mathrm{L} \infty-\mathrm{L}_{\max }}{\mathrm{L} \infty-\mathrm{L}^{\prime}}\right]^{\mathrm{Z} / \mathrm{K}}=\left[\frac{\mathrm{Z}\left(\mathrm{L}^{\prime}-\overline{\mathrm{L}}\right)+\mathrm{K}(\mathrm{L} \infty-\overline{\mathrm{L}})}{\mathrm{Z}\left(\mathrm{L}_{\max }-\overline{\mathrm{L}}\right)+\mathrm{K}(\mathrm{L} \infty-\overline{\mathrm{L}})}\right]}
\end{aligned}
$$

where $\mathrm{L}_{\max }=$ Maximum length of a specimen in the sample $(\mathrm{cm})$; and $\overline{\mathrm{L}}=$ Mean length of all fishes with lengths above L' (cm)

The $\mathrm{Z}$ value used for subsequent analysis was the mean value derived from the two methods.

\subsection{Fishing mortality}

This rate was just estimated by the difference between total and natural mortality

$\mathrm{F}=\mathrm{Z}-\mathrm{M}$

\subsection{Survival rate}

The annual survival rate (S) is estimated by the formula:

$$
\mathrm{S}=\mathrm{e}^{\mathrm{z}} .100
$$

\subsection{Natural mortality $(M)$}

The empirical equation proposed by Pauly (1980) was used to calculate natural mortality.

$$
\begin{aligned}
& 1 \mathrm{nM}=-0.0152-0.279 .1 \mathrm{~nL}_{\infty}+0.6543 .1 \mathrm{nK}+ \\
& 0.463 .1 \mathrm{nT}
\end{aligned}
$$

where $\mathrm{M}=$ Coefficient of natural mortality (year ${ }^{-1}$ ); and $\mathrm{T}=$ mean annual water temperature, which is assumed to be equal to the mean annual air temperature $\left({ }^{\circ} \mathrm{C}\right)$.

\subsection{Relative yield per recruit analysis $\left(Y^{\prime} / R\right)$}

The relative yield per recruit model of Beverton and Holt (1966) was used to estimate the yield per recruit:

$$
\frac{\mathrm{Y}^{\prime}}{\mathrm{R}}=\mathrm{EU}^{\mathrm{m}}\left[1-\left(\frac{3 \mathrm{U}}{1+\mathrm{m}}\right)+\left(\frac{3 \mathrm{U}^{2}}{1+2 \mathrm{~m}}\right)-\left(\frac{\mathrm{U}^{3}}{1+3 \mathrm{~m}}\right)\right]
$$

where $\mathrm{U}=1-\left(\frac{\mathrm{L}_{\mathrm{c}}}{\mathrm{L} \infty}\right) ; \mathrm{m}=\frac{1-\mathrm{E}}{\frac{\mathrm{M}}{\mathrm{K}}}=\frac{\mathrm{K}}{\mathrm{Z}} ;$ and $\mathrm{L}_{\mathrm{c}}=$ length at the beginning of the fishery recruitment

$\mathrm{E}$ is the exploitation rate, given by:

$$
\mathrm{E}=\frac{\mathrm{F}}{\mathrm{Z}}
$$

For fisheries management, it is necessary to adopt some reference points for the Beverton and Holt (1966) model. The most used ones are: $\mathrm{F}_{\max }$ and $\mathrm{F}_{0.1} \cdot \mathrm{F}_{\max }$ is the mortality level when the yield is at a maximum, as a function of a given catch length. $\mathrm{F}_{0,1}$ was proposed by Gulland and Boerema (1973) as the fishing mortality rate where the slope of the yield per recruit curve is $10 \%$ of its value at the origin.

\section{Results}

In 1996, 5146 specimens of pacus were sampled, while in 1997 this number amounted to 4921. The highest number of specimens measured during 1996 came from samples taken in April and August (993 and 939 specimens, respectively). During 1997, the highest number of specimens measured, 856 and 897, occurred during April and September, respectively. The mean furcal length for 1996 was $49.6 \mathrm{~cm}$, with a maximum value of $69 \mathrm{~cm}$, while during 1997 this value equaled $46.2 \mathrm{~cm}$, with a maximum value of $68 \mathrm{~cm}$. The distributions of individual furcal lengths are shown in Figure 1 for 1996 and 1997.

Biometric relationships for the pacu were only calculated from specimens caught between November 1999 and January 2000. During this period, 363 specimens were caught and the following measurements were taken: standard length, furcal length, total length and total weight. Mean furcal length was $38.4 \mathrm{~cm}$, with a maximum and minimum value of, respectively, 57 and $30 \mathrm{~cm}$. Mean total weight was $1536 \mathrm{~g}$, with a minimum and maximum value of, respectively, 685 and $4985 \mathrm{~g}$.

Estimated population parameters of pacu are shown in Table 1. In general, no difference was observed between values obtained in 1996 and 1997. These results

Table 1. Estimates of the population parameters of pacu Piaractus mesopotamicus, landed at Corumbá, MS, between 1996 and 1997. $\mathrm{L}_{\infty}$ - asymptotic length; $\mathrm{K}$ - curvature parameter of the VBGF; WP - winter point $=\mathrm{ts}+0.5$, where ts is the summer point; $\mathrm{Rn}$ - 'goodness of fit' index of the ELEFAN I routine $\left(=10^{\mathrm{ESP} / \mathrm{ASP})} / 10\right) ; \mathrm{M}$ - natural mortality; $\mathrm{Z}$ - total mortality; F - fishing mortality.

\begin{tabular}{ccccccccc}
\hline Year & $\mathbf{L}_{\infty}(\mathbf{c m})$ & $\mathbf{K}\left(\right.$ year $\left.^{-1}\right)$ & $\mathbf{C}$ & $\mathbf{W P}$ & $\mathbf{R n}$ & $\mathbf{M}\left(\right.$ year $\left.^{-1}\right)$ & $\mathbf{Z}\left(\right.$ year $\left.^{-1}\right)$ & $\mathbf{F}\left(\right.$ year $\left.^{-1}\right)$ \\
\hline 1996 & 87.2 & 0.34 & 0.74 & 0.81 & 0.154 & 0.620 & 1.518 & 0.898 \\
1997 & 86.5 & 0.34 & 0.60 & 0.8 & 0.125 & 0.630 & 1.655 & 1.025 \\
\hline
\end{tabular}



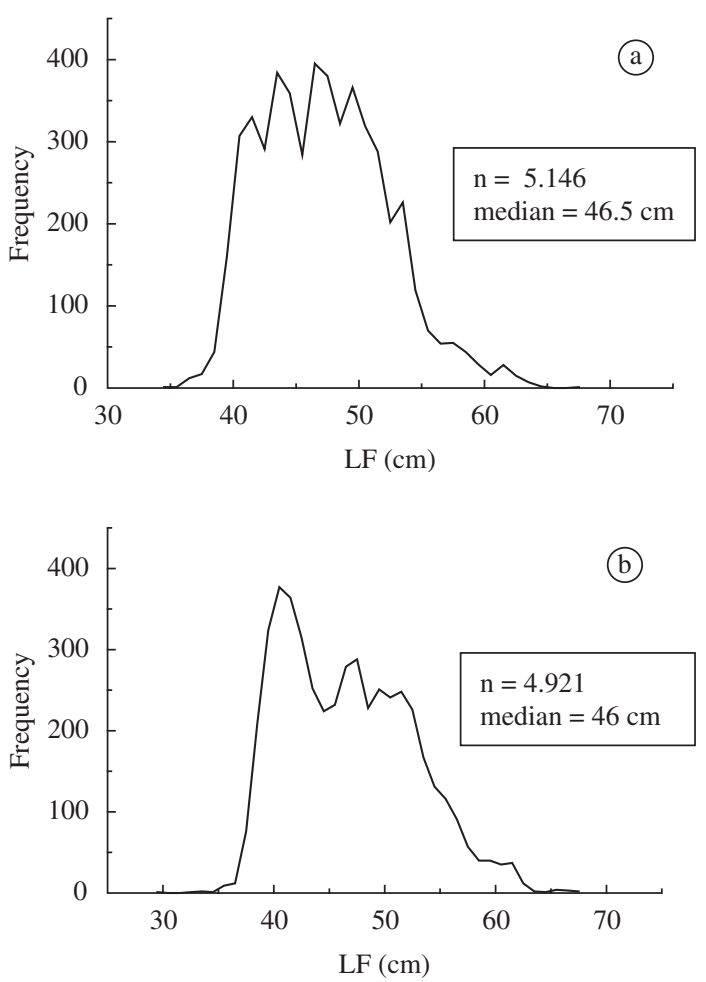

Figure 1. Furcal length $(\mathrm{cm})$ frequency distribution of pacu Piaractus mesopotamicus landed at Corumbá, Pantanal, between a) March 1996; and b) October 1997.

suggest oscillation in the growth rate, with a minimum occurring in September, which corresponds to the dry season in the Pantanal. The growth performance index $(\phi ')$ was equal to 3.41 , and its longevity was estimated as 8.4 years. The parameters associated with total and fishing mortalities were estimated as $Z_{1996}=1.518$ year $^{-1}$ and $\mathrm{F}_{1996}=0.898$ year $^{-1}$ and $\mathrm{Z}_{1997}=1.655$ year $^{-1}$ and $\mathrm{F}_{1997}=1.025$ year $^{-1}$. Survival rates were $\mathrm{S}_{1996}=21.9 \%$ and $\mathrm{S}_{1997}=19.1 \%$.

Yield per recruit analysis was based on mean values for 1996 and 1997, where $\mathrm{L}_{\infty}=86.85 \mathrm{~cm}$, $\mathrm{K}=0.34$ year $^{-1}, \mathrm{M}=0.625$ year $^{-1}, \mathrm{Z}=1.580$ year $^{-1}$, $\mathrm{F}=0.960$ year $^{-1}$. Figure 2 shows the curves for different values of $\mathrm{L}_{\mathrm{c}}$. Such values were obtained according to the following specifications:

- $\mathrm{L}_{\mathrm{c}}=26.7 \mathrm{~cm}$ : length of the smallest fish caught with a hook during the experimental fishing, (Peixer, 2003);

- $\mathrm{L}_{\mathrm{c}}=32.5 \mathrm{~cm}=$ length of the smallest fish caught during 1996 and 1997;

- $\mathrm{L}_{\mathrm{c}}=38 \mathrm{~cm}=$ Minimum catch length established by law during 1996 and 1997; and

- $\mathrm{L}_{\mathrm{c}}=42.6 \mathrm{~cm}=$ Minimum catch length established by law during 2002 .

$\mathrm{F}_{2002}=0.960$ year $^{-1}$ surpassed the maximum value $\mathrm{F}_{\max }=0.679$ year $^{-1}$ for $\mathrm{L}_{\mathrm{c}}=26.7 \mathrm{~cm}$ and 0.933 year $^{-1}$ for $\mathrm{L}_{\mathrm{c}}=32.5$ (Table 2). For the other values, $\mathrm{L}_{\mathrm{c}}=37.9 \mathrm{~cm}$

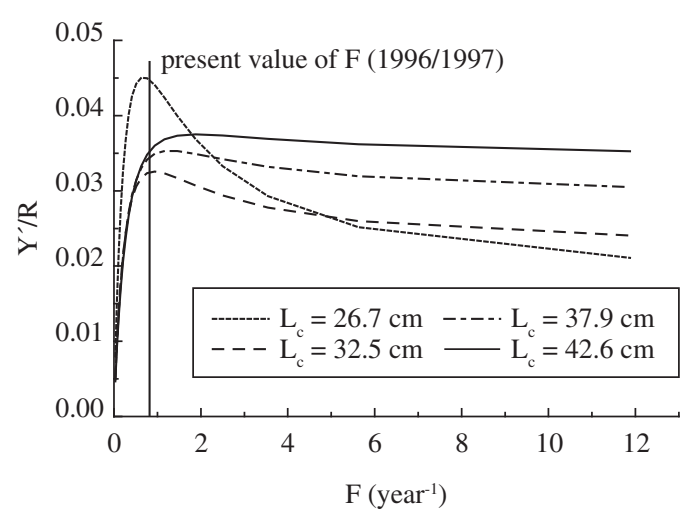

Figure 2. Yield per recruit ( $\left.\mathrm{Y}^{\prime} / \mathrm{R}\right)$ and fishing mortality (F) for the pacu Piaractus mesopotamicus between 1996/1997, according to several fishing recruitment length $\left(\mathrm{L}_{\mathrm{c}}, \mathrm{cm}\right)$.

Table 2. Length at the first capture $\left(\mathrm{L}_{\mathrm{c}}\right)$ and reference points $\left(\mathrm{F}_{\max }\right.$ and $\left.\mathrm{F}_{0.1}\right)$ for the pacu Piaractus mesopotamicus based on the data collected in 1996 and 1997. Values estimated from the yield per recruit equation.

\begin{tabular}{ccc}
\hline $\mathbf{L}_{\mathbf{c}}(\mathbf{c m})$ & $\mathbf{F}_{\max }\left(\right.$ year $\left.^{-1}\right)$ & $\mathbf{F}_{\mathbf{0 . 1}}\left(\right.$ year $\left.^{\mathbf{1}}\right)$ \\
\hline 26.7 & 0.679 & 0.515 \\
32.5 & 0.933 & 0.785 \\
37.9 & 1.292 & 1.011 \\
42.6 & 1.883 & 1.472 \\
\hline
\end{tabular}

and $42.6 \mathrm{~cm}, \mathrm{~F}_{\max }$ are, respectively, 1.292 year $^{-1}$ and 1.883 year $^{-1}$, (Table 2 ).

For $\mathrm{F}_{0.1}$ the values for each value of $\mathrm{L}_{\mathrm{c}}$ are: $26.7 \mathrm{~cm}=0.515$ year ${ }^{-1} ; \quad 32.5 \mathrm{~cm}=0.785$ year ${ }^{-1}$; $37.9 \mathrm{~cm}=1.011$ year $^{-1} ; 42.6 \mathrm{~cm}=1.472$ year $^{-1}$ (Table 2). It can be seen that for the highest Lc values, this reference point was already surpassed.

The present exploitation rate is equal to 0.607 . Thus, for $\mathrm{L}_{\mathrm{c}}=26.7 \mathrm{~cm}\left(\mathrm{E}_{\max }=0.52\right)$ and for $\mathrm{L}_{\mathrm{c}}=32.5 \mathrm{~cm}$ $\left(\mathrm{E}_{\max }=0.599\right)$, this value is above $\mathrm{E}_{\max }$ (Table 3). For the other values of $\mathrm{L}_{\mathrm{c}}(37.9$ and $42.6 \mathrm{~cm}), \mathrm{E}_{\max }$ values are 0.674 and 0.751 respectively, which are very close to the present exploitation rate (Figure 3).

\section{Discussion}

Values for the oscillation parameters (C) in Table 1 indicate slower growth during unfavorable periods, which corresponds to the dry season in the Pantanal $(\mathrm{WP}=0.8$ ). This lower WP value took place in September. Pacu is an omnivorous species, with a diet mostly composed of vegetable items. As usual, the period with the highest growth rate corresponded to flooding periods, whereas the period with the slowest growth rate corresponds to the dry season, when food is relatively scarce, as usual and in agreement with Vaz (2001). Isaac and Ruffino (1996) found C $=0.505$ and the highest WP value during July for the tambaqui Colossoma macropomum, a close relative of the pacu, in the Lower Amazon. According to 
Table 3. Estimates of the growth parameters for the pacu Piaractus mesopotamicus obtained in this study as compared to those obtained in other studies. $\mathrm{L}_{\infty}$ - asymptotic growth; $\mathrm{K}$ - growth rate; and $\phi^{\prime}=\log _{10} \mathrm{~K}+2 \cdot\left(\log _{10} \mathrm{~L}_{\infty}\right)$.

\begin{tabular}{lcccc}
\hline \multicolumn{1}{c}{ Authors } & $\mathbf{L}_{\infty}(\mathbf{c m})$ & K $\left(\right.$ year $\left.^{-1}\right)$ & $\phi^{\prime}$ & Longevity (years) \\
\hline Vaz (2001) & 89.32 & 0.48 & 3.55 & 4.60 \\
Ferraz de Lima (1984b) & 75.53 & 0.14 & 2.91 & 19.67 \\
\hline This study & & & & \\
1996 & 87.20 & 0.34 & 3.41 & 8.40 \\
1997 & 86.50 & 0.34 & 3.40 & 8.40 \\
\hline
\end{tabular}

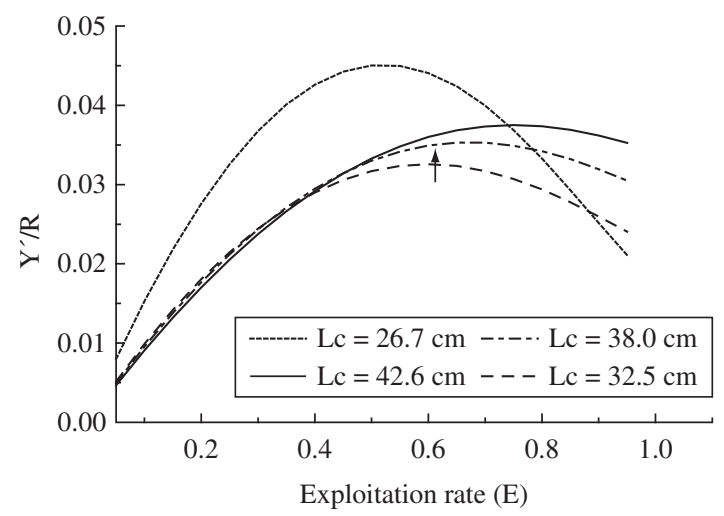

Figure 3. Relative yield per recruit versus exploitation rate for the pacu Piaractus mesopotamicus as a function of several fishing recruitment length $\left(\mathrm{L}_{\mathrm{c}}, \mathrm{cm}\right)$. The arrow indicates the present exploitation rate.

these authors, during July the water level is decreasing whereas the period of highest growth rate was associated with those months in which the water level was higher and hence, food availability is not a limiting factor for frugivore species, such as the tambaqui.

Vaz (2001) concluded that growth rings of $P$. mesoptamicus were formed twice a year. The first during September, matching the reproductive migration, while the other was formed in February during the trophic migration. Similar results concerning growth ring formation were reported by Mateus and Petrere (2004) for the "pintado" (Pseudoplatystoma corruscans), from the Cuiabá River basin, and by Penha et al. (2004) for the "jurupensem" (Sorubim cf. lima) from the Cuibá River.

The growth performance index calculated in this study was equal to 3.41 , a value similar to those obtained by Vaz (2001). Ferraz de Lima et al. (1984b) did not calculate this index but, through the analysis of their data, it was possible to estimate it as being equal to 2.91. According to Sparre and Venema (1997), this index is the best way to calculate the average of the growth parameters of a given species and should not differ widely when one compares different groups of data from the same species. If the difference is too high, then one might become suspicious about the estimate of the parameters $\mathrm{K}$ and $\mathrm{L}_{\infty}$.

Differences in $\mathrm{L}_{\infty}$ and $\mathrm{K}$ values shown in Table 3 can be partially attributed to differences in the way the model was adjusted.
The longevity estimated in this study was estimated as $\mathrm{Tm}=8.4$ years. Vaz (2001) found 4.6 years using the parameters estimated by ELEFAN, and a maximum age of 5 years through scale reading. Ferraz de Lima et al. (1984b) found a very high estimate for longevity, 19.6 years. This difference might be due to the fact that, in order to calculate longevity, it is necessary to estimate the parameters $\mathrm{t}_{0}$ and $\mathrm{K}$. These parameters, in turn, were quite different among the studies, as they were obtained by different methods. It is worth mentioning that those two studies that used scale analysis also reached quite different estimates for longevity (Vaz, 2001; Ferraz de Lima et al. 1984b). Probably, this difference rests on the fact that one study (Vaz, 2001) found the formation of two growth rings per year, while the other (Ferraz de Lima et al. 1984b) detected the formation of a single growth ring during the reproductive period without any further validation. It is also possible that the small sample size analyzed by Ferraz de Lima et al. (1984b) somehow biased his results.

The natural mortality rate found in this study ( 0.62 year $\left.^{-1}\right)$ was high, but still lower than the one presented by Vaz (2001), who estimated $M=0.78$ year $^{-1}$, using the same Pauly (1980) formula.

Based on the total mortality rates per year, the survival rate $\mathrm{S}_{1996}=$ was $21.9 \%$ and $\mathrm{S}_{1997}=19.1 \%$. These values are slightly higher than the value of $S=17.6 \%$ found by Vaz (2001).

The fishing mortality rate was estimated at 0.96 year $^{-1}$ and the yield per recruit analysis indicated that the reference point, directly estimated by ELEFAN, $\mathrm{F}_{\max }$ varied from 0.67 to 1.88 year $^{-1}$ for the different values of $\mathrm{L}_{c}$. For the lowest lengths, $\mathrm{F}_{\max }$ was already surpassed and for the two values of minimum catch length (37.9 and $42.6 \mathrm{~cm}$ ), $\mathrm{F}_{\text {Present }}$ is very close to $\mathrm{F}_{\max }$. Moreover, the fishing mortality rate that maximizes the yield per recruit is very high and probably exceeded $\mathrm{F}_{\mathrm{MSY}}$ (Clark, 1991). In some situations it has been observed that $\mathrm{F}_{\text {max }}$ exceeded $\mathrm{F}_{\mathrm{MSY}}$ (production models) and, therefore, $\mathrm{F}_{\max }$ has been regarded as a less conservative estimate (Gallucci et al., 1996; Quinn II and Deriso, 1999; Caddy and Mahon, 1995).

With respect $\mathrm{F}_{0.1}$, since the yield curve typically becomes more shallow as mortality rate increases, this estimate approaches the maximum yield per recruit (Clark, 1991). Furthermore, the increase in $\mathrm{F}$ above $\mathrm{F}_{0.1}$ leads to a smaller profit in terms of yield per recruit, even though there is considerable increase in the costs (Butterworth et al. 1989). This reference point is recognized, both 
from an economical and biological point of view, as denoting conservative exploitation (Martínez-Garmendia, 1997).

The yield per recruit analysis might not be adequate to describe multispecific fisheries, where interactions are intense and usually not well recognized (Pauly, 1979; Brothers, 1979). However, according to Petrere (1983), who used this method for the tambaqui, which being an omnivorous fish, would have a reduced interaction with other species and, hence, the yield per recruit analysis would be adequate in such case. Given that the pacu is also an omnivorous species, the rationale of Petrere (1983) should also hold for the present study.

Caddy and Mahon (1995) argued that, for those wellstudied fisheries, the coefficient of variation associated with $\mathrm{F}$ values might be lower than $15-30 \%$. On the other hand, coefficients of variation estimated from less-studied fisheries are usually higher. Thus, this might be another fact that should be taken into account when control actions are established for the fishing of pacu, especially when a conservative strategy is to be adopted.

The use of hooks for the pacu fisheries leads to the catch of specimens above $26.7 \mathrm{~cm}$ (LF), (Peixer, 2003). Thus, it can be concluded that the fishing mortality starts from this length. It is worth mentioning that the maximum reference point was surpassed for this fishery recruitment length. The present minimum length determined by the current legislation is $45 \mathrm{~cm}$ and there is no safe information as to the survival rate of individuals below this minimum length that are caught and released. If the mortality after release (catch-and release fishery) is higher, the adoption of this strategy might not be efficient to account for stock renewing and, thus, new regulation strategies must be adopted to protect this species.

The reference point $\mathrm{F}=\mathrm{M}$, would also be already surpassed, indicating that the pacu is overexploited in the Pantanal. Deriso (1987) argued that, whenever the $\mathrm{M} / \mathrm{K}$ ratio is between 1 and 4 , this reference point is a value that does not depart widely from the $\mathrm{F}_{0,1}$ point. In the present study, $\mathrm{M} / \mathrm{K}=1.838$, and the variation in $\mathrm{F}_{0.1}$ ranged from 0.5 to 1.4 , an interval which included the natural mortality rate $(0.625)$. Thus, this data seems to corroborate the suggestion of Deriso (1987), at least for the smallest catch lengths.

Vaz (2001) found that the pacu had a fishing mortality equal to 0.955 year $^{-1}$ for $\mathrm{F}_{\text {Present }}$ and, in that case, $\mathrm{F}_{\text {MSY }}=1$, when $\mathrm{M}=0.78$ year $^{-1}$. Thus, this author concluded that this species is close to its maximum sustainable yield.

Using the surplus production model, Catella (2001) concluded that the maximum sustainable yield of the pacu had already been exceeded. This author used data from landings for 1994 and 1995 for the entire basin of the Upper Paraguay River at the State of Mato Grosso do Sul. He found a $\mathrm{Y}_{\mathrm{MSY}}=430 \mathrm{t} /$ year and $\mathrm{F}_{\mathrm{MSY}}=149.691$ fishers per fishing day. The fishing effort during 1999 was 243.982 fishers per fishing day and the production amounted to $314 \mathrm{t}$, which was lower than the
1994 production (452 t). Del Barco (2000) also concluded that the pacu is overexploited in the Paraná River in Argentina.

The excessive fishing effort decreases not only the potential catches and catch rates, but also the stock size up to a point where reproduction is jeopardized and a collapsing level is reached (Garrod, 1987). Over-fishing also leads to a narrow group of age classes that are effectively caught, and to a decrease in the mean length of the specimens caught (Caddy and Mahon, 1995).

Calcagnotto (1998), based on data derived from mitochondrial DNA analysis of the pacu, concluded that this species represents a single genetic pool. Thus, if the results from the present study corroborate those from Catella (2001) and Vaz (2001), it can be safely assumed that its stock is presently overexploited and urgent action has to be taken in order to prevent its collapse.

Acknowledgments - We thank UNESP and CNPq for partially supporting this research. Dr. Lúcia Ap. de Fátima Mateus and Dr. Gonzalo Velasco Canziani for help with the FISAT software and for critically reading an early draft of this manuscript. Thanks are also due to EMBRAPA Pantanal for logistic support and for assembling length data, and to the fishing tourism companies of Corumbá, Cooperativa de Pesca and several fish markets that facilitated collection of length data.

\section{References}

AULT, JS. and EHRHARDT, M., 1991. Correction to the Beverton and Holt Z-estimator for truncated catch lengthfrequency distributions. ICLARM Fishbyte, vol. 9, no. 1, p. 37-39.

BARCO, MBV., PETRERE, M., VILLAREAL, MZ. and VERA, EG., 1993. Parámetros poblacionales (mortalidad, rendimento máximo sostenible) y estado de explotación del bocachico (Prochilodus magdalenae Steindachner, 1878; Prochilodontidae) del Bajo Río Magdalena (Colombia). Boletin Cientifico INPA, vol. 1, p. 43-60.

BEVERTON, RJH. and HOLT, SJ., 1966. Manual of methods for fish stock assessment. Part 2. Tables of yield functions. FAO Fish. Tech. Pap. 38. 67p.

BROTHERS, EB., 1979. Age and growth studies on tropical fishes. In ROEDEL, PM., SAILA, SB. (ed.). Stock assessment for tropical small-scale fisheries. University of Rhode Island/ ICMRD, 198p.

BUTTERWORTH, DS., PUNT, AE., BORCHERS, DL., PUGH, JB., HUGHES, GS., 1989. A manual of mathematical techniques for linefish assessment. South African National Scientific Programmes Report $n^{\circ} 160$. Cape Town, (Marine Linefish Programme's), 89p.

CADDY, JF. and MAHON, R., 1995. Reference points for fisheries management. Roma: FAO, 83p.

CALCAGNOTTO, D. 1998., Caracretização de bancos genéticos selvagens de pacu (Piaractus mesopotamicus) e de tambaqui (Colossoma macropomum) através da análise do DNA mitocondrial. (PhD Thesis) - Instituto de Biociências. Universidade de São Paulo, São Paulo, 131p.

CATElla, AC., 2001. A pesca no Pantanal de Mato Grosso do Sul, Brasil: descrição, nível de exploração e manejo (1994- 
1999). (PhD Thesis) - INPA - Instituto Nacional de Pesquisas da Amazônia, Universidade do Amazonas, Manaus, 343p.

CLARK, WG., 1991. Groundfish exploitation rates based on life history parameters. Can. J. Fish. Aquat. Sci., Ottawa, vol. 48, p. 734-750.

DEL BARCO, DM., 2000. Informe sobre la situación actual de la actividad pesquera en la provincia de Santa Fe. Seminario Internacional de Pesca Continental. Santa Fé, Argentina, 6 e 7 dezembro. (não publicado).

DERISO, RB., 1987. Optimal F0,1 criteria and their relationship to maximum sustainable yield. Can. J. Fish. Aquat. Sci, Ottawa, vol. 44 , sup. 2, p. 339-348.

FERRAZ DE LIMA, JA., BARBIERI, G. and VERANI, JR., 1984a. Período de reprodução, tamanho e idade de primeira maturação gonadal do pacu, Colossoma mitrei, em ambiente natural (Rio Cuiabá, Pantanal de Mato Grosso). In Anais Simp. Brás. de Aquicul. III. São Carlos, SP, 477-497.

FERRAZ DE LIMA, JA., FERRAZ DE LIMA, CLB. and BARBIERI, G., 1984b. Crescimento do pacu (Colossoma mitrei), em ambiente natural (Rio Cuiabá - Pantanal de Mato Grosso). In Anais Simp. Bras. Aquicul. III. São Carlos, SP, p. 499-521.

GALLUCCI, VF., AMJOUN, B., HEDGEPETH, J. and LAI, HL., 1996. Size-based methods of stock assessment of smallscalle fisheries. In GALLUCCI, VF., SAILA, BS., GUSTAFSON, DJ. and ROTHSCHILD. (eds). Stock assessment: quantitative methods and applications for small-scale fisheries. New York. Lewis Publishers, p. 9-81.

GARROD, DJ., 1987. The scientific essentials of fisheries management and regulations. Lowestoft: Ministry of Agriculture Fisheries and Food/ Directorate of Fisheries Research. 14p. (Laboratory, 60).

GAYANILO, FC. JR. and PAULY, D. 1997. FAO-ICLARM stock assessment tools (FISAT) Reference Manual. Roma: FAO, $262 \mathrm{p}$.

GULLAND, JA. and BOEREMA, LK., 1973. Scientific advice on catch levels. Fishery Bulletin, vol. 71, no. 2, p. 325-335.

HILBORN, R. and WALTERS, CJ., 1992. Quantitative fisheries stock assessment: choice, dynamics and uncertainty. New York: Chapman and Hall, $570 \mathrm{p}$.

HOLDEN, M., 1995. Beverton and Holt revisited. Fisheries Research, Dartmouth, vol. 24, no. 1, p. 3-8.

ISAAC, VJ., RUFFINO, ML., 1996. Population dynamics of tambaqui, Colossoma macropomum Cuvier, in the Lower Amazon, Brazil. Fisheries Management and Ecology, vol. 3, no. 4, p. 315-333.

MARTÍNEZ-GARMENDIA, J., 1997. Effects of length-at-age data on growth and management benchmark $\mathrm{F}_{0,1}$ estimates in the face of size-selective mortality. Fisheries Research, vol. 32, no. 3, p. 233-247.

MATEUS, LAF. and PETRERE, JR. M., 2004. Age, growth and yield per recruit analysis of the pintado Pseudoplatystoma corruscans (Agassiz, 1829) in the Cuiabá River Basin, Pantanal Matogrossense, Brazil. Braz. J. Biol., vol. 64, no. 2, p. 257-264.

PAULY, D., 1979. Theory and management of tropical multispecies stocks: a review with emphasis on the Southeast Asian demersal fisheries. ICLARM Stud. Rev. 1, 35p.

-, 1980. On the interrelationships between natural mortality, growth parameters and mean environmental temperature in 175 fish stocks. J. Cons. CIEM, vo. 39, no. 3, p. 175-192.

PAULY, D. and MARTOSUBROTO, P., 1980. The population dynamics of Nemipterus marginatus (Cuvier \& Val.) off Western Kalimantan, South China Sea. J. Fish Bio., vol. 17, no. 3, p. 263-273.

PAULY, D. and DAVID, N., 1981. ELEFAN I, a basic program for the objective extraction of growth parameters from lengthfrequency data. Meeresforsch, vol. 28, no. 4, p. 205-211.

PEIXER, J. 2003. A seletividade de anzol e o rendimento por recruta do pacu Piaractus mesopotamicus (Holmberg, 1887) no Pantanal de Mato Grosso do Sul, Brasil. (MSC dissertation) Universidade Estadual Paulista "Júlio de Mesquita Filho", Rio Claro, $77 \mathrm{p}$.

PENHA, JMF., MATEUS, LAF. and BARBIERI, G., 2004. Age and growth of the duckbill catfish (Sorubim cf. lima) in the Pantanal. Braz. J. Biol., vol. 61, no. 1, p. 125-134.

PETRERE, M., 1983. Yeld per recruit of the Tambaqui, Colossoma macropomum Cuvier, in the Amazonas State, Brazil. J. Fish Biol., vol. 22, no. 2, p. 133-144.

QUINN II, TJ., DERISO, RB., 1999. Quantitative fish dynamics. Oxford: Oxford University Press. 542p.

SILVA, MV., 1986. Mitos e verdades sobre a pesca no Pantanal sul-mato-grossense. Campo Grande, FIPLAN-MS. 146p.

SPARRE, P. and VENEMA, SC. 1997. Introdução á avaliação de mananciais de peixes tropicais. Parte 1 - Manual. FAO Documento Técnico sobre as Pescas, 306/1, Ver. 2, 404p.

TAYLOR, CC., 1960. Temperature, growth, and mortality - the pacific cockle. J. Cons. Int. Explor. Mer, vol. 26, no. 1, p. $117-124$.

VAZ, MM., 2001. Problemas no ajuste da curva de crescimento do pacu, Piaractus mesopotamicus (Holmberg, 1887) (Pisces: Characidae), e seu manejo no Pantanal Mato-Grossense. $\mathrm{PhD}$ Thesis CAUNESP - Centro de Aquicultura/Universidade Estadual Paulista, Jaboticabal, 98p.

WEATHERLEY, A. H. 1972. Growth and Ecoclogy of Fish Populations. London: Academic Press, 293p. 
